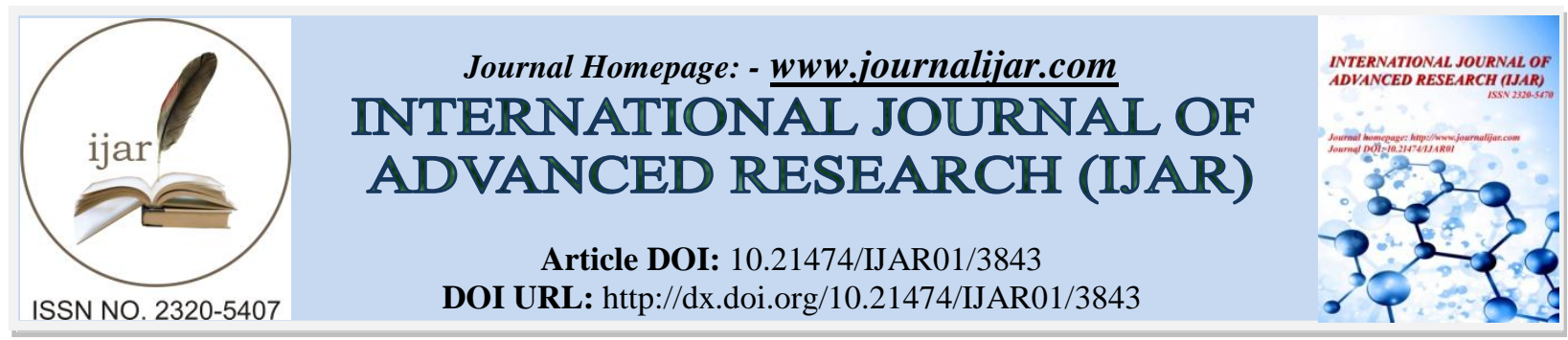

RESEARCH ARTICLE

\title{
PLANTS USED BY GOND AND BAIGA WOMEN IN ETHNOGYNAECOLOGICAL DISORDER IN PALI BLOCK UMARIA DISTRICT, M.P.
}

\author{
Radha Singh. \\ Department of Botany, Pt. S.N.S. Govt. Autonomous P.G. College Shahdol(M.P.)
}

\section{Manuscript Info}

Manuscript History

Received: 01 February 2017

Final Accepted: 10 March 2017

Published: April 2017

Key words:-

Ethnogynaecology, Gond \& Baiga

women, Pali block.

\begin{abstract}
Traditional medicines are still under practice in Indian villages and have been developed through experience of many generations. The present communication reports first hand information gathered on 15 plant species traditionally used by Gond and Baiga women of Pali block, Umaria district for the treatment of various diseases and disorders related to gynecological problems. Valuable information about the medicinal uses of certain plants against various diseases of the Gond and Baiga women were obtained through personal interviews and collection. The botanical names, families, local name, and locality of these collections are also given along with medicinal uses.
\end{abstract}

Copy Right, IJAR, 2017,. All rights reserved.

\section{Introduction:-}

Pali is a Tehsil in Umaria District of Madhya Pradesh state, India. Pali is a head quarter of Pali town. It belongs to Shahdol division. It is located $48 \mathrm{~km}$ towards East from district head quarter Umaria. Pali is located at $23.35^{\circ} \mathrm{N}$ $81.05^{\circ} \mathrm{E}$. It has an average elevation of 450 meters (1476 feet). The ethno-medicinal research is important aspects of ethno-botanical research. The tribal tracts are storehouse of information and knowledge on the multiple uses of plants. The common tribal communities are Gond, Kol, Baiga, Sahariya tribes. They are partially or completely dependent on forest product for their survival. Indigenous knowledge is a potential tool for searching new economic plants for uses of medicinal plants for various purposes by tribal. Most of the population lives in rural areas and mainly belongs to Gond tribes and other non tribal localities. Ethno-gynecology is an important field of study that deals with various diseases among Gond tribal societies and their major problems as sterility, conception, abortion etc. and the uses of plants as a medicines for these diseases. Very little work has been done on the ethnogynecological use of plants in the treatment and health-care program me of women as evidenced by the literature and reference.

\section{Material and Methods:-}

The survey to collect the data, presented in this paper was conducted during the period of july 2014-2015 in 03 village of the Pali block namely, Chhottumbi, Waghannara, and Majouli. The local tribal medicine man or herbal informants were selected and their views regarding the subject matter were used. It has been observed during survey that the chief trainer women play a significant role in discussions since them posses more cognizance's about the utility of local herbal products in curing various melodies. Data on the preparation of ethno-herbal recipes along with their application were gathered from experienced and knowledgeable medicine man and women. More than fifteen plants were reported to be commonly used in medicine in this block. There are some plants which are used in Gynecological problems. Details are given below. 


\begin{tabular}{|c|c|c|c|c|}
\hline S.NO & LOCAL NAME & BOTANICAL NAME & FAMILY & USES \\
\hline 01 & Chirchita & Achyranthus aspera & Amaranthaceae & $\begin{array}{l}\text { The fresh root is tied around the thump } \\
\text { of right leg for easy delivery. }\end{array}$ \\
\hline 02 & Sataver & Asparagus racemosus & Asparagaceae & $\begin{array}{l}\text { Boiled tuberous roots are eaten to the } \\
\text { increase lactation in women. } \\
\text { 2. Leaf juice (two teaspoon a day)is } \\
\text { given during pregnancy for easy } \\
\text { delivery. }\end{array}$ \\
\hline 03 & Gwarpatha & Aloe vera & Liliaceae & $\begin{array}{l}\text { Juice of leaves is given to lesson labor } \\
\text { pain during delivery. }\end{array}$ \\
\hline 04 & Bhatkatai & Argemone maxicana & Papaveraceae & $\begin{array}{l}\text { Dried root powder used as tea for } \\
\text { regulating fertility. } \\
\text { The ripe fruits are smoked and said to } \\
\text { be useful in venereal disease. } \\
\text { Leaves juice is given in leucorrhoea. }\end{array}$ \\
\hline 05 & Sitaphal & Annona squamosa & Annonaceae & $\begin{array}{l}\text { Leaf decoction is drunk for easy } \\
\text { delivery. One spoon of seed powder } \\
\text { with a cup of water taken for 3-4 days } \\
\text { for abortion. }\end{array}$ \\
\hline 06 & Palas & Butea monosperma & Caesalpiniaceae & $\begin{array}{l}\text { Paste of the bark is applied to treat } \\
\text { gonorrhea. }\end{array}$ \\
\hline 07 & Amaltash & Cassia fistula & Caesalpiniaceae & $\begin{array}{l}\text { Paste of the flower is applied on the } \\
\text { affected part to treat gonorrhea. }\end{array}$ \\
\hline 08 & Chawokra & Cassia tora & Casealpiniaceae & $\begin{array}{l}\text { Young seedling of the plants after } \\
\text { washing is chewed by pregnant women } \\
\text { for timely and easy delivery. }\end{array}$ \\
\hline 09 & Amarbel & Cuscuta reflexa Roxb & Convolvulaceae & $\begin{array}{l}\text { For anti fertility. Powder of seeds used } \\
\text { orally }\end{array}$ \\
\hline 10 & Kala datura & Datura metel & Solanaceae & $\begin{array}{l}\text { One tea spoon root powder given twice } \\
\text { a day for } 15 \text { days after menstruation for } \\
\text { permanent sterility. }\end{array}$ \\
\hline 11 & Kulthi & Dolichos biflorum & Leguminosae & $\begin{array}{l}\text { Decoction of seeds is used orally in } \\
\text { leuchorrhoea. }\end{array}$ \\
\hline 12 & Sissum & Dalbergia sisoo Roxb & Papilionceae & $\begin{array}{l}\text { Extract of leaves is taken daily in the } \\
\text { morning to cure leuchorrhoea } \\
\text { Decoction of leaves is useful in the } \\
\text { diarrhea }\end{array}$ \\
\hline 13 & Dudhi & Euphorbia hirta & Euphorbiaceae & $\begin{array}{l}\text { Leaves are crushed and the extract is } \\
\text { taken orally with honey once a day in } \\
\text { the morning for leuchorrhoea for a } \\
\text { month. }\end{array}$ \\
\hline 14. & Kapas & Gossypium arboretum & Malvaceae & $\begin{array}{l}\text { Root bark is used for a menorrhea and } \\
\text { dysmenorrhoea. }\end{array}$ \\
\hline 15. & Nirgundi & Vitex negundo & Verbenaceae & $\begin{array}{l}\text { One teaspoon powder of young root is } \\
\text { used for restore fertility. }\end{array}$ \\
\hline
\end{tabular}

\section{Results and Conclusion:-}

During the survey it has been observed that although tribal of this Pali block are still in primitive stage of economic life and depend upon wild resources around them for their needs, they posses fairly good knowledge about the medicinal uses of plants. Due to the constant association with the forest environment and in the absence of any other medical facility available to them in their localities, they have evolved curious knowledge by the method of tribal and have developed their own way of treatment of ailment.

The present findings indicate that tribal women of the study area have deep faith in traditional medicine. They seem to depend upon the plants for curing various disease including abortion, sterility, conception disorder, menstrual 
troubles, leucorrhoea etc. Prevailing among them. Traditionally they do not go to a doctor or a clinic but depend upon herbal treatment suggested by old ladies (Chief trainers) or experienced medicine men of the village.

\section{Acknowledgement:-}

I have great pleasure in expressing my whole hearted thanks to department faculty and tribal women and medicine man of Pali block village, for kindly sharing their knowledge with us, for their suggestions and faithful discussion during the field survey. I am also thankful to UGC for providing me financial support. (MRP No.F.No-MS26/11023/XII/13-14/CRO dated 20 June 2014.

\section{References:-}

1. Audichya,K.C., Billore. K.V. Joseph, T.H. \& Chaturvedi, D.D. 1983.Role of indigenous folk remedies for certain acute illnesses in primary health care. Nagarjum 26: 199-201.

2. Anonymous.1985. Ethnobotany of Baigas of Madhya Pradesh.NBRI Newslett.12: 28-29.

3. Arora, R.A. 1997.Ethnobotany and its role in the conservation and use of plant genetic resources in India.Ethenobotany 9:6-15.

4. Bhalla, N.P. Sahu.,Mishra,G.P. \& Dakwale, R.N.1982. Traditional plant medicine of Sagar Distt., MadhyaPradesh, India .J. Econ. Taxon. Bot. Addl.Ser.12:175-178.

5. Brij Lal.1993.Ethonobotany of Baigas of Madhya Pradesh-a preliminary report.Arunachal Forest News 11(1):17-20.

6. Bodhe,P.D.,Sharma,L.K.\& Pandey,V.K.1997.Rare folk medicine practiced by Gond tribes of wadsa forest division,Gadchirol district, Maharashtra.Bull.Medico-Ethnobot.Res.18(1\&2):12-17.

7. Bondya, S.L. \& Sharma ,H.P.2004. Ethnobotanical studies on plants used in diabetes (Madhumeha) under the Baharagora Block of Jharkhand. Ethnobotany 16:139-140.

8. Borthakur, S.K. 1993. Native phytotherapy for child and women disease from Assam.Ethnobotany 75:87-89

9. Balgir R.S.2004a.Dimensions of rural tribal health, nutritional status of Kondh tribe and tribal welfare in Orissa: a biotechnological approach. Proceeding of the UGC Sponsored National Conference on Human Health and Nutrition: ABiotechnological Approach(Lead Lecture),12-13 ${ }^{\text {th }}$ December 2004.Thane.pp.47-57.

10. Dwivedi,S.N.,Dwivedi,S.\&Patel,P.C.2005.Herbal remedies used by thr rural people in the treatment of joint disease.Ethnobotany 17:193-196.

11. Hemadri, K \& Rao, S.S.1983.Leucorrhoea and menorrhoea: Tribal medicine. Anc. Sci. Life 3:40-41.

12. Hemadri, K.\& Rao,S.S.1989a.Folk medicine of Bastar. Ethnobotany 1:61-66.

13. Jain ,A.K. \& Sharma, H.O.1990.Certain medicinal plants used by Sahariya tribals of northern Madhya Pradesh.Proc.Nat.Sem.Med.\& Arm. Plants Jabalpur 2:155-165.

14. Jain S.K.1963a. Studies in Indian Ethnobotany-I: Wild plants foods of the tribals of Bastar,Madhya Pradesh.Proc. Nation. Inst. Sci. India 30B:3.

15. Kumar, D. \& Yadav, A.2003. Ethnobotanical investigation of some medicinal plants availed by Gond tribes of Noradehi wildlife sanctuary, Madhya Pradesh. Anthropologist 5(3):201-202.

16. Lal, B.1993. Ethnobotany of Baigas of Madhya Pradesh - A preliminary survey.Arunacal Forest News.11(1): $17-20$.

17. Maheshwari, J.K.1989. Case studies of three primitive tribes (Abujhmarhia, Baiga and Bharia) of Central India. In S.K. Jain (ed.) Methods and Approaches in Ethnobotany,pp.187-188. SOE, Lucknow.

18. Maheshwari, J.K.1990a.Interaction of tribals with the forest. Trop. For. Ecosyst. Conserve. Develp. S.\& SE Asia,pp.115-126. Proc. MAB. Regional Workshop.

19. Maheshwari, J.K.1990b. Recent ethnobotanical research in Madhya Pradesh, SEB Newsletter 9(1-3):5.

20. Sikarwar R.L.S. (2002). Ethnogynaecological uses of plants new in India. Ethnobotany, 14: 112-115.

21. Tarafder C.R. (1983). Ethnogynoecology in relation to plants part-I plants for Ant fertility and conception. J.Econ. Tax. Bot., 4(2):483-489. 